TITLE:

\title{
The internal structure of a rockslide dam induced by the 2008 Wenchuan (Mw7.9) earthquake, China
}

\section{AUTHOR(S):}

Wang, Gonghui; Huang, Runqiu; Kamai, Toshitaka; Zhang, Fanyu

\section{CITATION:}

Wang, Gonghui ... [et al]. The internal structure of a rockslide dam induced by the 2008 Wenchuan (Mw7.9) earthquake, China. Engineering Geology 2013, 156: 28-36

\section{ISSUE DATE:}

2013-04

URL:

http://hdl.handle.net/2433/173357

\section{RIGHT:}

(c) 2013 Elsevier B.V.; この論文は出版社版でありません。引用の際には 出版社版をご確認ご利用ください。; This is not the published version. Please cite only the published version. 
Submitted to Engineering Geology

3

4 Title:

5 The internal structure of a rockslide dam induced by the 2008 Wenchuan $\left(\mathrm{M}_{\mathrm{w}} 7.9\right)$ earthquake, China

6

Authors: Gonghui Wang, Runqiu Huang, Toshitaka Kamai, Fanyu Zhang

8

Addresses of authors:

10 Gonghui Wang, Assistant Professor (Corresponding author)

11 Research Center on Landslides

12 Disaster Prevention Research Institute

13 Kyoto University

14 Gokasho, Uji, 611-0011

15 Japan

16 Tel: (+81)774-384114; Fax:(+81)774-384300

17 e-mail: wanggh@landslide.dpri.kyoto-u.ac.jp

Runqiu Huang, Professor

20 State Key Laboratory of Geo-hazard Prevention and Geo-environment Protection

21 Chengdu University of Technology

22 Chengdu, Sichuan 610059

23 P.R. China

Toshitaka Kamai, Professor

Disaster Prevention Research Institute

27

Kyoto University

28

Gokasho, Uji, 611-0011

29

Japan

30

Fanyu Zhang, Dr.

32

Disaster Prevention Research Institute, Kyoto University, Japan 
Abstract:

The internal structure of landslide dams plays a key role in their stability; however, it has not been much studied, probably due to the difficulty in obtaining information on internal structure in most cases. Here, we examined the shear-wave-velocity structure of a rockslide dam by a surface-wave technique called multichannel analysis of surface waves (MASW). During the 2008 Wenchuan earthquake $\left(M_{w} 7.9\right)$, more than 60,000 landslides were triggered and 800 landslide dams formed. Those dams with a high risk of collapse threatened rescue activities, and almost all of the large landslide dams were treated by digging a sluiceway immediately after the earthquake. Although the risk of collapse of many landslide dams was removed or lowered, not all of the countermeasures were based on well controlled methods. To analyze the internal of landslide dams to assist in carrying out reliable countermeasures, we made detailed investigations on some of the dams, and here describe one landslide dam that occurred in the Tianchi area. Grain-size analysis revealed that the displaced landslide materials experienced fragmentation and segregation during the long movement. The shear-wave-velocity profile of the dam revealed that the dam consisted of three facies (carapace, body and basal facies). The boundary between facies is distinct. The body facies had a greater shear-wave velocity (compared to those landside dams that had suffered collapse failure during the construction of a sluiceway), showing that the dam consisted of more densely deposited materials. This kind of dam body had a lower permeability, capable of retarding seepage that triggers collapse failure of the dam body due to piping. Big blocks on the surface also enabled the dam body to have greater resistance to overflow and thus reducing possible collapse failure in the immediate aftermath of overtopping. 
Introduction

Landslide dams form when large landslides block river flows, forming lakes. Landslide dams formed by such mass movements are often weak in structure, and can fail under their own weight or by overtopping. Sometimes the released water carrying landslide debris causes fatalities and substantial damage to properties downstream. For example, a landslide dammed Dadu River in an earthquake in Sichuan Province in 1786. Ten days later, the dam failed, resulting in a devastating flood that reached $1400 \mathrm{~km}$ downstream, killing about 100,000 people (Li et al., 1986).

In recent years, many landslide dams triggered by earthquakes and rainfall have been reported. They often cause great difficulties to the recovery phases in the hazard areas, and also threaten the safety of people living downstream. It is normally required to make a risk assessment of the stability of the dam within a short time immediately after the dam's formation (Tabatake et al. 2002). Two different approaches, the topographical approach (Costa \& Schuster 1988, 1991; Casagli \& Ermini 1999; Ermini \& Casagli, 2003; Korup, 2002, 2004) and the hydraulic approach (Mizuyama et al, 1987, 1989; Takahashi and Kuang, 1988; Takahashi and Nakagawa, 1993), have been developed to analyze the possible longevity of the dam and the flood profile when the dam is breached. The topographical characteristics and the breaching failure mechanisms due to overtopping have been widely examined. Nevertheless, our understanding of the formation of landslide dams is still poor; so many countermeasures for dealing with some giant landslide dams are empirically based. Normally, a landslide dam consists of heterogeneous displaced debris, with properties determined by the locality as well as by the movement of the landslide itself. Hence, in many cases, although the risk of dam breaching has been acknowledged and understood, there are still cases in which the dam has collapsed while countermeasures were being carried out. For example, in 2000, a giant rock avalanche formed a large landslide dam in the Yigong area, Tibet, China, and the main countermeasure was digging a sluiceway. However, the dam collapsed suddenly after the sluiceway was finished, resulting in severe downstream flooding, killing about 100 people downstream, and resulting in 5,000 people losing their homes (Zhu et al., 2003). Although this kind of catastrophic failure had occurred previously, the countermeasures for the Tangjiashan landslide dam formed in the 2008 Wenchuan 
earthquake in Sichuan, China (dam height: about $100 \mathrm{~m}$; dam volume: about $24 \mathrm{Mm}^{3}$; storage capacity of dammed lake: about $320 \mathrm{Mm}^{3}$ ) was also the construction of a spillway across the dam. Abrupt breaching occurred due to rapid erosion at the dam site, and a great flood threatened the cities downstream, such as Beichuan and Mianyang (Liu et al., 2009). Fortunately, only $1 / 3$ of the dam height was breached, and 2/3 of the dam height remained stable, preventing the release of the entire reservoir of water. On the other hand, some hundreds of tonnes of dynamite were used on another landslide dam (formed during the 2008 Wenchuan earthquake), in an attempt to make a spillway by blasting to lower the risk of an outburst flood in case the dam breached abruptly. However, the explosion only functioned to break the big rocks, and the landslide dam itself was stable enough. From these cases, we can conclude that a proper approach for analyzing whether a landslide dam is stable or not has not been set up from an engineering viewpoint.

During the 2008 Wenchuan $\left(M_{w} 7.9\right)$ earthquake, more than 90,000 people were killed due to the collapse of houses or landslides. The earthquake triggered 40 - 60 thousand landslides (Huang, 2009; Dai et al., 2011; Gorum et al., 2011) and more than 800 landslide dams were formed (Fan et al., 2012), greatly hindering recovery and reconstruction in the seismic hazard area. Almost all of the landslide dams failed naturally or were removed artificially soon after the earthquake. However, some of the larger landslide dams still remain, impounding large volumes of water, so there is still a major risk of outburst flooding. Therefore, it is of great importance to develop a fast and effective method to assess the risk of outburst flooding due to landslide dam failure.

To assist in assessing the risk of outburst flooding due to landslide dam failure, we carried out detailed field surveys of some of the big landslide dams formed during the 2008 Wenchuan earthquake, investigating the geological and topographical characteristics of the landslides, their processes of formation and the internal structure of the landslide dams. In this paper, through study of the landslide dam formed in Tianchi Town, Mianzhu City, we examine the formation of a landslide dam resulting from a long-travel rockslide occurring in a carbonate rock area. We surveyed the internal structure of the dam site by means of a multiple-channel surface-wave technique, and also analyzed the grain size distribution at the dam site. Based on the survey results, we discuss the dam's formation and stability. Fig. 1 shows the epicenter the 2008 Wenchuan earthquake, the 
locations of landslides and the location of the Tianchi landslide dam.

108

109

110

\section{Wenchuan earthquake and landslide dams}

On May 12,2008 , at $14: 28 \mathrm{hr}$ local time, an earthquake $\left(\mathrm{M}_{\mathrm{w}} 7.9\right)$, with a hypocentre at $30.99^{\circ} \mathrm{N}, 103.36^{\circ} \mathrm{E}$, at a depth of $19 \mathrm{~km}$ occurred in Sichuan province, China (USGS, 2008). This is known as the Wenchuan earthquake, named after the earthquake's epicenter in Wenchuan County (Fig. 1). The maximum ground acceleration recorded during the earthquake was at Wolong, $18 \mathrm{~km}$ WNW of the epicenter. Peak accelerations there were 957.7 gal in the East-West direction, 652.9 gal in the North-South direction, and 948.1 gal vertically (Li et al., 2008). The earthquake was felt as far away as Beijing (1500 km away) and Shanghai (1700 km away), and also in some nearby countries. Strong aftershocks continued to hit the area months after the main quake, causing further casualties and damage.

The 2008 Wenchuan earthquake occurred in the Longmen Shan thrust zone, which is located on the eastern boundary area of the Tibetan plateau. The Longmen Shan thrust zone is one of the most significantly deformed regions in China, with many seismically active faults (Burchfiel et al., 1995, 2008; Jia et al., 2006, 2007; Densmore et al., 2007). The thrust zone is about $60 \mathrm{~km}$ wide, and marks the topographic boundary between the eastern Tibetan Plateau and the Sichuan basin. The convergence rate across the thrust zone is inferred to be 4-6 mm/yr (Deng et al., 1994). Earthquakes occur frequently along this zone. In 1933, a M7.5 earthquake occurred in Diexi, $50 \mathrm{~km}$ northeast of Wenchuan. During this earthquake, some large lakes were formed behind landslide dams, and 6800 people were killed (about 2500 people were directly killed by the floods that followed collapse of two landslide dams). In 1976, two earthquakes (M7.2) occurred in Songpan and Pingwu, northeast of Chengdu.

In the Wenchuan earthquake area, the rocks in the vicinity of the Longmen Shan thrust zone are mainly composed of Triassic granite, metamorphosed sandstone, phyllite, sandy slate and dolomite (Ma, 2002). The rocks are closely jointed due to strong tectonic movement in this area. The adjacent Chengdu basin has been less affected by tectonic activity and remained relatively stable throughout the Cenozoic; here the strata of Jurassic 
132 and Cretaceous age are covered by Quaternary alluvium (Ma, 2002).

The earthquake formed more than 800 landslide dams (Fan et al., 2012), of which 104 had heights of $>10$ m, impounding $>10,000 \mathrm{~m}^{3}$ of water, and with catchment areas $>20 \mathrm{~km}^{2}$. Based on the scale of the landslide dam, degree of risk of each landslide dam was placed into one of three risk categories (high, medium and low). Of the landslide dams, 6 were at high risk, 25 were at medium risk and 72 were at low risk (Liu, 2008; Yin, 2008). Emergency treatment measures had been carried on many of the landslide dams. The emergency work on the Tangjiashan landslide dam was reported worldwide and attracted wide concern.

\section{Landslide dam in the Tianchi area}

The landslide dam in Tianchi town (hereinafter called the Tianchi landslide dam) (Fig. 2), about $100 \mathrm{~km}$ north of Chengdu, resulted from a rock avalanche occurring on the right slope of a tributary of the Mianyuan River in Mianzhu City. Fig. 2a shows a satellite image of the landslide area taken before the earthquake. Figs. 2b and $2 \mathrm{c}$ present an oblique view of the whole dam site and a view from upstream. Fig. $2 \mathrm{~d}$ shows a view of the dam from downstream, in which the piping is marked by a circle. From the Google Earth image and field investigation, we inferred that there was an unstable rock at the source area before the earthquake (marked as 'Unstable block' in Fig. 2a). The geological setting of the Tianchi area is presented in Fig. 3. The landslide area consists of Devonian clastics and carbonate (dolomite or dolomitic limestone). Bedding planes and joints of the bed rock in the source area were surveyed and are shown in Fig. 4, and they can be mainly divided into 5 groups.

The bedrock of the source area was fractured by these bedding planes and joints, and a big unstable wedge was formed on the bedrock near the mountain ridge (Fig.4a). This unstable wedge failed during the earthquake, and traveled downslope rapidly $(\sim 28.5 \mathrm{~m} / \mathrm{s}$, Wang et al., 2011), burying the river channel, and climbing the slope of the opposite bank. A landslide dam was formed, with a dam height of 34-41 m, a length (along the river channel) of $158 \mathrm{~m}$, and a width (across the river channel) of 70-102 m. The city hall, elementary school, and some houses 
in Fig. 2a. For the cross section in Fig. 5, the topography after the quake was measured by a laser measuring technique (Trupulse360), while the topography before the quake was inferred from maps and field investigation.

The landslide dam is located on a tributary of the Miyuan River. The local engineers thought that the was almost constant.

No engineering work was undertaken on the Tianchi landslide dam for about one and half years after the earthquake. Thereafter, following the need for recovery and reconstruction work upstream of the landslide dam, before the earthquake. Fig. 6 shows the status of excavation of the channel at different times (Fig.6a on June, 2010). The channel had been excavated in three steps at the time of our first survey, and had reached the original bed river at the time of our second survey (June, 2010). The progressive channel excavation enabled us to perform a geophysical survey using a surface wave technique called the multichannel analysis of surface waves (MASW) and also carry out grain-size-distribution analysis of the soil layers in the dam at different depths.

\section{Internal structure of the landslide dam}

The surface of Tianchi landslide dam was almost completely covered by very large boulders (c. 2-6 $\mathrm{m}$ in diameter). Observations of the soil layers in the dam exposed as channel construction progressed revealed that the boulders were mostly in the surficial soil layer; immediately below the surficial layer were small boulders $(<$ $0.5 \mathrm{~m}$ ), gravels and finer debris. To analyze the grain-size distribution of soil layers at different depths within the dam, we analyzed grain size by sieving and photography. The reliability of this combined method for grain size distribution analysis has been verified by Casagli et al (2003). We performed the analysis by following steps. 
182 different soil layer levels, reshaping the face locally to be vertical. Two orthogonally oriented scales were put on 183 the vertical surface, and photographs were taken.

(2) For the target measuring area, the area ratios of grains with differing sizes were calculated by photographic analysis. After taking the photo, the grain in each photograph was outlined by drawing a line along its boundary. Using the outlined figure, the diameter (the diameter of the inscribing cycle of the outline) and the cross section area of each grain were calculated, and the total cross section area of grains with the same diameter was then calculated. Considering the possibility of human error in drawing the outlines of grains, we used a photographic analysis method to analyze the larger grains with $\varphi>4.75 \mathrm{~mm}$.

(3) We took samples from the surface of the photographed area, sieved out those gravels with $\varphi>50 \mathrm{~mm}$, and took $10 \mathrm{~kg}$ of samples $(\varphi \leq 50 \mathrm{~mm})$ to the laboratory for further grain size analysis by sieving following the ASTM standard.

(4) The percentages of grains with different grain sizes were calculated. Assuming that the debris has the same density, the percentages by weight of grains with differing sizes were calculated through the area ratio (obtained by particle digital image analysis) of different grains and the results from sieving analysis.

We sampled 11 locations for the distribution of grain size in the Tianchi landslide dam (Fig. 6a). Samples P1 - P8 were taken on November 2009, and P9 - P11 on June 2012. P1 - P4 and P8 are located on the upper steps along the road, P5 - P7 are on the side slope of the excavation at level L3. P9 - P11 are located at the bottom of the excavation (about $2 \mathrm{~m}$ above the outcropping former river bed). $\mathrm{P} 9$ is near the downstream margin of the landslide dam, while P10 is below P7, and P11 is below P5. Fig. 7 presents the grain-size distributions. Because very large boulders were located only in the surficial layer, there were no grains $>50 \mathrm{~cm}$ in Fig. 7. From 202 the grain size distribution of P1 - P4, and P8 (Fig. 7a), we saw that the grains tended to become coarser closer to the lateral margins (say, P8 and P9). This tendency is normal in the deposits of large-scale rock avalanches (Schulz et al., 2008; Crosta et al., 2011; Davis and McSaveney, 2011; Dunning and Armitage 2011), due to the 
layers of the dam site, and the distance between them was relatively short.

To investigate the internal structure of the landslide dam, we used a surface-wave method known as multichannel analysis of surface waves (MASW) (Park et al., 1999; Hayashi and Suzuki, 2004) to measure the shear-wave velocity profile of the landslide-dam site. The survey principle of MASW and the layout of equipment (Seismograph: Model McSEIS-SXW, OYO Corporation, Tokyo, Japan; Geophones: Model GS-11D, OYO Geospace Corporation, Houston, Texas, USA) are outlined in Fig. 8. In the survey, 24 geophones were hammer points were outside of both ends of the survey line and also intermediate between the geophones. We carried out our first survey in November 2009, when the landside dam had been excavated with the shape shown in Fig. 6b. The landslide dam excavation had three steps (L1, L2 and L3), with the most upper one (L1) along the original road before the earthquake and exposed during the excavation. Step L3 (shown by dashed line) was flat at the time of our survey, although it was later dug deeper as excavation progressed. In June of 2010, we surveyed this area again, when the excavation had been finished, and the bottom of the excavation had reached almost to the original river bed level (L4). Hereinafter, we call these survey lines L1, L2, L3, and L4, respectively. Fig. 9 show the shear-wave velocity profile along survey line L1, and Fig.10 along survey lines L2 to L4. As mentioned above, $\mathrm{L} 1$ is along the original road. The shear-wave velocity values obtained along this line thus represent those of the slope before the earthquake. As shown in Fig. 9, most of the field has shear-wave velocity values ranging from 400-480 m/s. However, around $30 \mathrm{~m}$ from the beginning point and at a depth of 9 $\mathrm{m}$, shear-wave velocity values are smaller (ranging from $350-400 \mathrm{~m} / \mathrm{s}$ ). This field of smaller shear-wave velocity values might reflect the former channel of the stream, i.e., landslide debris buried the stream path, with the soil layer deposited being looser than the surrounding original mountain slope. 
232 surface to the bottom) 0-30 $\mathrm{m}$ from the upstream end of the line had relatively smaller shear-wave velocity values (330-390 m/s) (Fig. 10a). Most of the soil layer along L3 showed greater shear-wave velocity values (400 $\mathrm{m} / \mathrm{s}-480 \mathrm{~m} / \mathrm{s}$ ) (Fig. 10b). However, the domain on the middle part of the survey line (30-60m) and 7-10m deep had relatively smaller shear-wave velocity values $(330 \mathrm{~m} / \mathrm{s}-400 \mathrm{~m} / \mathrm{s})$. Although the grain size of the soil layer near this area was not measured, from the grain size distribution of the surficial soil layers in L3 (P5-P7 in Fig. 7b), we can infer that the effective grain size $\left(\mathrm{D}_{10}\right)$ tended to become smaller. If it is assumed that the soil density is everywhere constant, the rigidity modulus becomes smaller with decrease of gravel content. Because the shear-wave velocity $\mathrm{V}_{\mathrm{s}}=-(G$ : Rigidity modulus; $\rho$ : mass of soil layer $)$, the smaller the rigidity modulus is, the smaller the shear-wave velocity becomes. Therefore, we infer that the area with smaller shear-wave velocity (shown in the ellipsoidal area) might result from a segregation phenomenon as shown in Fig. 7. Due to the segregation process during movement, finer debris accumulated in this area, forming soil layers that are relatively weaker than the surrounding domain. The soil layer below line L4 showed high shear-wave velocity values $(400 \mathrm{~m} / \mathrm{s}-480 \mathrm{~m} / \mathrm{s})$ in general, with a small area with relative low shear-wave velocities $(330-390 \mathrm{~m} / \mathrm{s})$. $(250-300 \mathrm{~m} / \mathrm{s})$. This may partially result from the original fluvial river-channel deposits and also the entrained substrate mixed with rockslide debris.

\section{Discussion}

It has been noted that breaching of landslide dams normally results from three types of failure processes (Takahashi and Kuang, 1988), i.e., overtopping erosion, occurrence of slides on the whole dam, and progressive failure. It has also been noted that overtopping breaching is dominant in breached landslide dams, and that progressive dam failure due to seepage (piping flow) is rare (Mizuyama et al., 1987, 1989). However, of the 32 big landslide dams that formed during the 2008 Wenchuan $\left(M_{w} 7.9\right)$ earthquake and had engineered channels excavated in them, 8 failed from piping flow (Xu et al. 2009). Thus, in the case of the Wenchuan earthquake, 
257 that consisted of finer grained debris of sand and gravels suffered breaching due to overtopping erosion. On the other hand, landslide dams consisting of coarser materials (such as gravels and huge boulders) showed greater stability (Chigira et al., 2010; Wang, 2011). been proposed by Ermini and Casagli (2003).

$$
D B I=\log \left(\begin{array}{ll}
A_{b} & H_{d} / V_{d}
\end{array}\right)
$$

where $A_{b}$ is area of the catchment $\left(\mathrm{km}^{2}\right) ; H_{d}$ is height of the landslide dam (m); $V_{d}$ is volume of the landslide dam $\left(\times 10^{6} \mathrm{~m}^{3}\right)$. Based on the analysis of many recorded landslide dams all over the world, Ermini and Casagli (2003) recognized three "stability domains" for the dimensionless blockage index (1) when $D B I<2.75$, the landslide dam lies in the stability domain; (2) when $2.75<D B I<3.08$, the landslide dam is in the uncertain domain; and (3) when $D B I>3.08$, the landslide dam is in the instability domain.

For Tianchi landslide dam, its length is about $158 \mathrm{~m}$, width 70-102 m, and height 34-41 m, the upstream catchment area is about $30.83 \mathrm{~km}^{2}$. Equation 1 indicated a Dimensionless Blockage Index value of 3.72. Hence, Tianchi landslide dam could be regarded to lie in the instability domain. However, no breaching occurred before the channel was excavated. This suggested that the landslide dam itself was stable. It is noted that during the channel excavation on some other large landslide dams formed in the same earthquake in Sichuan, such as Tangjiashan, Xiaojiaqiao, and Xiaogangjian, etc, abrupt dam breaching occurred, resulting in catastrophic flooding downstream. In Fig. 11, we superimposed the plot of catchment area against $V_{d} / H_{d}$ together with those obtained by Ermini \& Casagli (2003), where SD means the stability domain, UD instability domain. The risk of abrupt breaching of some large landslide dams formed in the 2008 Wenchuan earthquake is correctly indicated by the Dimensionless Blockage Index, with the exception of the Tianchi landslide dam. This may be due to the fact that the Dimensionless Blockage Index is based on topographic features of the landslide dam and the upstream catchment area, without consideration of the dam's geotechnical properties. Such anomalous behavior has also been reported by Strom (2010), who suggests that additional quantitative parameters characterizing landslide dams and dammed lakes should be used in the stability analysis of landslide dams. However, although 
282 the geotechnical properties of landslide dams play a key role in dam stability and also in the resistance to overtopping erosion, they have been rarely incorporated before now, probably due to the difficulties in obtaining them.

We surveyed the shear-wave velocity profiles of several large landslide dams formed in the 2008 Wenchuan earthquake, and found that those dams that abruptly breached during the construction of the sluiceway had shear-wave velocity values smaller than $250 \mathrm{~m} / \mathrm{s}$ (Wang, 2011). It is known that the standard penetration test $\mathrm{N}$ value of a soil layer has a positive correlation with the shear-wave velocity (Imai and Tonouchi, 1982). A higher shear-wave velocity value means that the soil layer has greater penetration resistance, indicating that the soil layer is more tightly consolidated. From Fig. 10 we can see that almost all the domains of Tianchi landslide dam have greater shear-wave velocity values (say, $>300 \mathrm{~m} / \mathrm{s}$ ). Therefore, we conclude that the landslide dam is in a tightly consolidated state, so no abrupt breaching could occur during the discharge of impounded water after the channel excavation was finished. The greater shear-wave velocities may be due to the fact that the landslide debris with high mobility rushed into the river valley, and was deposited there suddenly, leading to the debris being tightly consolidated. Such tightly consolidated landslide dams may be less likely to experience slides compared to loosely deposited landslide dams (Foster et al., 2000).

According to Dunning and Armitage (2011), rock-avalanche deposits generally exhibit three sedimentatry facies: i.e., a carapace facies (the coarsest unit composing the surface and near surface), a body facies (the main body of the rock-avalanche deposit), and a basal facies (the base of the rock-avalanche deposit). The boundary between the basal facies and the body facies is often indistinct in the field. Our MSWA survey showed that these three facies were easily identified from the shear-wave velocity profile (Fig. 10). The carapace and basal facies have smaller shear-wave velocities, while the body facies occupying the main area of the deposits has greater shear-wave velocities. Therefore, the shear-wave velocity profile enables us to not only identify the distribution of these facies, but also to estimate the geotechnical properties of each facies. 
hydraulic prediction have been proposed, based on experimental work on landslide dams consisting of homogenous soil layers. However, as revealed by the grain size distribution of Tianchi landslide dam, a landslide dam normally consists of heterogeneous debris. Therefore, in the analysis of a landslide dam formed by breaching risk due to overtopping, the effects of very large boulders in the surficial layers should be taken into account. As in the case of the Tianchi landslide dam, the giant boulders $(\phi=2 \sim 6 \mathrm{~m})$ of the surficial layer can elevate the resistance to overtopping erosion, and thus retard the occurrence of sudden breaching. On the other hand, as pointed by Dunning and Armitage (2011), the presence of a coarse layer (carapace facies) in the upper part of the landslide dam may enhance permeability, so that the upper layer may become saturated rapidly after overtopping, resulting in rapid breaching. However, the finer materials inside the landslide dam are tightly consolidated and can lower the seepage and lead to a lower water table in the downstream dam body. In this case, even if overtopping occurs, the soil layers in the downstream part of the dam may not be saturated quickly, so collapse failure may not occur.

It is noted that at present there is no accepted rapid approach to predict the stability of a landslide dam immediately after its formation. However, we expect that a method combinating the Dimensionless Blockage Index and shear-wave velocity survey results could be developed so that the risk of abrupt breaching of a landslide dam can be assessed rapidly and more reliably. In the future, we plan to carry out similar geophysical surveys on more landslide dams with differing topographic, geological and movement characteristics to develop a physically based method of assessing the breaching risk of landslide dams.

\section{Conclusions}

To understand the formation and mechanisms allowing abrupt breaching of landslide dams that formed during the 2008 Wenchuan $\left(\mathrm{M}_{\mathrm{w}} 7.9\right)$ earthquake, a landslide dam that resulted from a long-runout rockslide in the 
(1) Tianchi landslide resulted from the failure of an unstable rock block in the source area. The displaced landslide mass traveled a long distance, colliding with the opposite river bank, and damming the river. Because the bedding planes and the joints in the source area were well developed, the landslide debris consisted of many very large boulders.

(2) Segregation phenomenon occurred within the displaced debris. After a long distance of movement, the larger boulders formed surficial layer, the coarse carapace facies found on many rock avalanche deposits. The debris was much finer deeper within the landslide dam.

(3) A seismic geophysical survey of the landslide dam revealed that the soil layers inside the dam had

layer (carapace facies) and the bottom layer (basal facies) have relatively smaller shear-wave velocities values.

Some domains of the central part of the dam also show relatively smaller shear-wave velocities-namely, some relatively weaker layers are sandwiched in the landslide dam.

(4) Tianchi landslide dam was covered by huge boulders but consisted of tightly consolidated finer materials. This kind of dam structure can resist overtopping erosion and reduce the likely occurrence of piping, thus retarding breaching immediately after the occurrence of overtopping flow. understand the internal structure of landslide dams with differing geological and topographic backgrounds and differing movement mechanisms. The target landslide dams are those triggered by the 2008 Wenchuan earthquake in China, by the 2004 Niigata Prefecture Chuetsu earthquake in Niigata, Japan, and by heavy rainfall during the 2011 Typhoon Talas in Kii Peninsula, Japan. By doing so, we are expecting to enhance the reliability in the analysis of stability of landslide dam with help of shear-wave velocity profiles.

Acknowledgments : 
357 grant from the MEXT of Japan (Grant No. 21403002), and a 2009 special event fund for promotion of disaster

358 prevention research, DPRI, Kyoto University (SA21-06). We are grateful to Dr. Wei Hu (Chengdu University of 359 Technology), Prof. Masahiro Chigira (Kyoto University), Prof. Xiyong Wu (Southwest Jiaotong University), Dr.

360 Fei Cai (Gunma University), Dr. Sergio Lourence (Cardiff University), and Dr. Murice McSaveney (GNS

361 Science, New Zealand), for their help and valuable discussions on this work. Valuable English editing by Dr. 
363

364

365

366

\section{References}

Burchfiel, B.C., Chen, Z., Liu, Y., Royden, L.H., 1995. Tectonics of the Longmen Shan and adjacent regions, central China, International Geological Review 37, 661-735.

Burchfiel, B.C., Royden, L.H., van der Hilst RD, Hager, B.H., 2008. A geological and geophysical context for the Wenchuan earthquake of 12 May 2008, Sichuan, People's Republic of China, GSA Today 18

Casagli, N., Ermini, L., 1999. Geomorphic analysis of landslide dams in the northern Apennine. Transactions of the Japanese Geomorphological Union 20, 219- 249.

Casagli, N., Ermini, L. Rosati G. 2003. Determining grain size distribution of the material composing landslide dams in the Northern Apennines: sampling and processing methods. Engineering Geology, 69(1-2): 83-97

Chigira, M., Wu, X.Y., Inokuchi, T., Wang, G., 2010: Landslides induced by the 2008 Wenchuan earthquake, Sichuan, China. Geomorphology, 118(3-4.: 225-238.

Costa, J.E., Schuster, R.L., 1988. The formation and failure of natural dams, Geological Society of America Bulletin 100, pp. 1054-1068

Costa, J.E., Schuster, R.L., 1991. Documented historical landslide dams from around the world. U.S. Geological Survey Open-FileReport 91-239, 1-486.

Crosta, G.B., Frattini, P., Fusi, N., Sosio, R. 2011. Formation, characterization, and modeling of the Val Pola rock-avalanche dam (Italy). Chapter 12, in Natural and Artificial Rockslide dams (Evans, Hermanns, Strom, and Scarascia-Mugnozza, eds.), Springer, pp:347-368

Dai, F.C., Xu, C., Yao, X., Xu, L., Tu, X.B. and Gong, Q.M., 2011. Spatial distribution of landslides triggered by the 2008 Ms 8.0 Wenchuan earthquake, China. Journal of Asian Earth Sciences, 40(4): 883-895

Deng Q, Chen S, Zhao X., 1994. Tectonics, seismicity, and dynamics of the Longmen Shan Mountains and its adjacent regions, Seismological Geology 16: 389-403 (in Chinese)

Densmore, A.L., Ellis, M.A., Li, Y., Zhou, R., Hancock, G.S., Richardson, N., 2007. Active tectonics of the Beichuan and Pengguan faults at the eastern margin of the Tibetan Plateau, Tectonics 26: TC4005 
387 Dunning, S.A., Armitage, P.J., 2011. The grain-size distribution of rock-avalanche deposits: implications for natural dam stability. Chapter 19 in Natural and Artificial Rockslide dams (Evans, Hermanns, Strom, and Scarascia-Mugnozza, eds.), Springer, pp: 497-498.

Davies, T.R., McSaveney, M.J., 2011. Rock-avalanche size and runout - implications for landslide dams. Chapter 17 in Natural and Artificial Rockslide dams (Evans, Hermanns, Strom, and Scarascia-Mugnozza, eds.), Springer, pp: 441-462.

Ermini, L., Casagli, N., 2003. Prediction of the behaviour of landslide dams using a geomorphological dimensionless index. Earth Surface Processes and Landforms, 28(1): 31-47.

395

Fan, X., Gorum, T., Cees J. van Westen, Korup, O., Xu, Q., Dai, F., Huang, R., Wang, G., 2012. Transient water and sediment storage of the decaying landslide dams induced by the 2008 Wenchuan earthquake, China. Geomorphology 171-172: 58-68.

Foster, M.A., Fell, R., Spannangle, M., 2000. The statistics of embankment dam failures and accidents. Canadian Geotechnical Journal 37(5), 1000-1024.

Gorum, T., Fan, X.M., van Westen, C.J., Huang, R.Q., Xu, Q., Tang, C., Wang, G., 2011. Distribution pattern of earthquake-induced landslides triggered by the 12 May 2008 Wenchuan earthquake. Geomorphology 133(3-4):152-167.

Hayashi, K., Suzuki, H., 2004. CMP cross-correlation analysis of multi-channel surface-wave data. Explor. Geophys., 35 (2004), pp. 7-13

Huang, R.Q., 2009. Geohazard assessment of the Wenchuan Earthquake. Science Press, 944P (in Chinese)

Imai, T., Tonouchi, K., 1982. Correlation of N-value with S-wave velocity and shear modulus. Proc. 2nd European Symp. Of Penetration Testing (Amsterdam), 57-72.

Jia, D., Wei, G., Chen, Z., Li, B., Zeng, Q., Yang, G., 2006. Longmen Shan fold-thrust belt and its relation to the western Sichuan Basin in central China: new insights from hydrocarbon exploration, AAPG Bulletin 90: 1435-1447. 
Jia, Q., Jia, D., Zhu, A., Chen, Z., Hu, Q., Luo, L., Zhang, Y., Li, Y. 2007. Active tectonics in the Longmen thrust belt to the eastern Qinghai-Plateau and Sichuan Basin: evidence from topography and seismicity, Chinese Journal of Geology 42: 31-44.

Korup, O., 2002. Recent research on landslide dams - a literature review with special attention to New Zealand, Progress in Physical Geography 26, 206-235.

Korup, O., 2004. Geomorphometric characteristics of New Zealand landslide dams. Engineering Geology 73, $13-35$

Li, H., Fu, X., Van Der Woerd, J., Si, J., Wang, Z., Hou, L., Qiu, Z., Li, N., Wu, F., Xu, Z., Tapponnier, P., 2008. Co-seismic surface rupture and dextral-slip oblique thrusting of the Ms 8.9 Wenchuan Earthquake. Acta Geologica Sinica 82, 1623-1643.

Li, T., Schuster, R.L., Wu, J., 1986. Landslide dams in south central China. In: Schuster, R.L. (Ed.), Landslide Dams Processes, Risk and Mitigation, Special Publication vol. 3. ASCE, pp. 146- 162.

Liu, N., 2008. Lesson from the countermeasures on lowering the risk of the dammed lakes formed by large landslides during the 2008 Wenchuan earthquake. Journal of China Water Resources 16,1-7 (in Chinese)

Liu N., Zhang J.X., Lin, W., Cheng W.Y., Chen Z.Y., 2009. Draining Tangjiashan barrier lake after Wenchuan earthquake and the flood propagation after the dam break. Science in China Series E: Technological Sciences, 52(4): 801-809.

Li, X., Zhou, Z., Yu, H., Wen, R., Lu, D., Huang, M., Zhou, Y., Cu, J., 2008. Strong motion observations and recordings from the great Wenchuan Earthquake. Earthquake Engineering and Engineering Vibration 7, $235-246$.

Ma LF (ed.). 2002. Geological atlas of China, Geological Publishing House, 348p

Mizuyama, T., Ishikawa, Y., Fukumoto, A., 1987. Landslide dams outburst due to seepage. Annual of Public Works Research Institute, Vol.2744, 18-91 (in Japanese).

Mizuyama, T., Ishikawa, Y., Fukumoto, A., 1989. Landslide dams outburst and its Countermeasure. Civil Engineering Journal, Vol.31-11; 50-56 (in Japanese). 
Park, C.B., Miller, R.D., Xia, J., 1999. Multichannel analysis of surface waves. Geophysics, 64 (3), 800-808.

437

438

439

440

441

442

443

444

Schulz, W.H., Harp, E.L., Jibson, R.W., 2008. Characteristics of large rock avalanches triggered by the November 3, 2002 Denali Fault earthquake, Alaska, USA, Proc. $10^{\text {th }}$ ISL, Xian, China, June 30-July 4, 2008, Taylor and Francis Group, London, 1447-1453.

Sherard, J.L., 1979. Sinkholes in dams of coarse, broadly graded soils, 13th ICOLD Congress, India, Vol. II, pp. $25-35$.

Strom, A., 2010. Landslide dams in Central Asia region. Journal of the Japan Landslide Society 47(6), 309-324.

Tabatake, S., Mizuyama T., Inoue, K., 2002. Landslide dam and hazards, Kokon Press, 205pp.

Takahashi, T., Kuang, S.F., 1988. Hydrograph prediction of debris flow due to failure of landslide dam. Annuals, Disas. Prev. Res. Inst., Kyoto Univ., No.31 B-2: 601-615.

Takahashi, T., Nakawaga H., 1993. Flood and Debris flow hydrograph due to collapse of a natural dam by overtopping. Journal of Hydroscience and Hydraulic Engineering, JSCE, 37: 699-704.

USGS, 2008. Website (http://earthquake.usgs.gov/eqcenter/eqinthenews/2008/us2008ryan/), accessed on September 17, 2012.

Wang, G., 2011. Formation of large scale landslide dams and failure prediction. Proceedings of 2011 landslide symposium, Kansai Branch of Japan Landslide Society, pp:65-80 (in Japanese).

Wang, Q., Wang, Y.S., Jiang, Y.A., Wei, P., Zhi, Z.Z., 2011. The initiation mechanism and movement process of Tianchi landslide. Gansu Water Conservancy and Hydropower Technology 47(1):16-18 (In Chinese).

Xu, Q., Fan, X.M., Huang, R.Q., Van Westen, C.J., 2009. Landslide dams triggered by the Wenchuan Earthquake, Sichuan Province, south west China. Bull Eng Geol Environ 68:373-386.

Yin, Y.P., 2008. Researches on the Geo-hazards triggered by Wenchuan Earthquake, Sichuan, Journal of Engineering Geology 16: 433-444 (in Chinese).

Zhu, P.Y., Wang, C.H., Wang Y.C., 2003. Large-scale landslide-debris avalanche in Tibet, China, (2) formation of an exceptionally serious outburst flood from a landslide dam in Tibet. Landslide News, International newsletter of the Japan Landslide Society, 14/15: 23-25. 
461

462

463

464

465

466

467

468

469

470

471

472

473

474

475

476

477

478

479

480

481

482

483

484

485

486

487

488

489

490

\section{Captions:}

Fig. 1 Epicenter of the Sichuan earthquake, the distribution of landslides, and location of the Tianchi landslide dam (after Huang and Li, 2009).

Fig. 2 Landslide dam in the Tianchi area: (a) satellite image of landslide area before the quake; (b) view of the landslide from upstream of the dam after channel excavation (taken on March 19, 2011); (c) landslide dam and lake (Courtesy of F. Cai, taken on November 7, 2008 by F. Cai); (d) landslide dam viewed from downstream (Courtesy of F. Cai, taken on November 7, 2008)

Fig.3 Geological settings of the Tianchi area - 1: Stratum boundary; 2: Fault; 3: Tianchi landslide area; 4: Quaternary alluvial and diluvial deposit; 5: Triassic sandstone, conglomerate, siltstone and mudstone; 6: Triassic shale; 7: Triassic clastic rock and carbonate rock; 8: Permian shale, limestone and basalt; 9: Devonian sandstone and conglomerate with carbonate rock; 10: Devonian clastic rock and carbonate rock; 11: Silurian slate; 12: Cambrian shale, siltstone, mudstone and sandstone; 13: Cambrian dolomite; 14: Sinian dolomite and marble; 15: Proterozoic acid volcanic, clastic rock and carbonate rock; 16: Proterozoic granite; 17: Diabase dike (after Ma, 2002)

Fig. 4 (a) Source area of the landslide; (b) Stereonet plot of rock-mass discontinuities in the source area

Fig. 5 Longitudinal section along line I-I' in Fig. 2a

Fig. 6 (a) Photograph of landslide dam after excavation, with locations of shear-wave velocity survey lines and grain-size sampling points (P1-P11); (b) Cross section of the landslide dam at differing surveying times. L3, L4: spillway levels on November 20, 2009, and June 16, 2010, respectively.

Fig. 7 Grain size distributions of materials from dam body: (a) samples on the same altitude level, (b) samples at different depths within the dam body

Fig. 8 Measurement principle of multichannel analysis of surface waves (MASW). 
491 Fig. 9 Shear-wave velocity profile along traverse line L1

492

493 Fig. 10 Shear-wave velocity profile of the dam body. (a), (b), (c): results for traverse line L2, L3 and L4,

494 respectively

495

496 Fig.11 Stability analysis using Dimensionless Blockage Index (after Ermini and Casagli (2003)) $\boldsymbol{\Delta}$ : intact

:collapsed landslide dams 
498

499

500

501

502

503

504

505

506

507

508

509

510

511

512

513

514

515

516

517

518

519

520

521

522

523

524

525

526

527

528

529

530

531

532

533

534

535

Figures

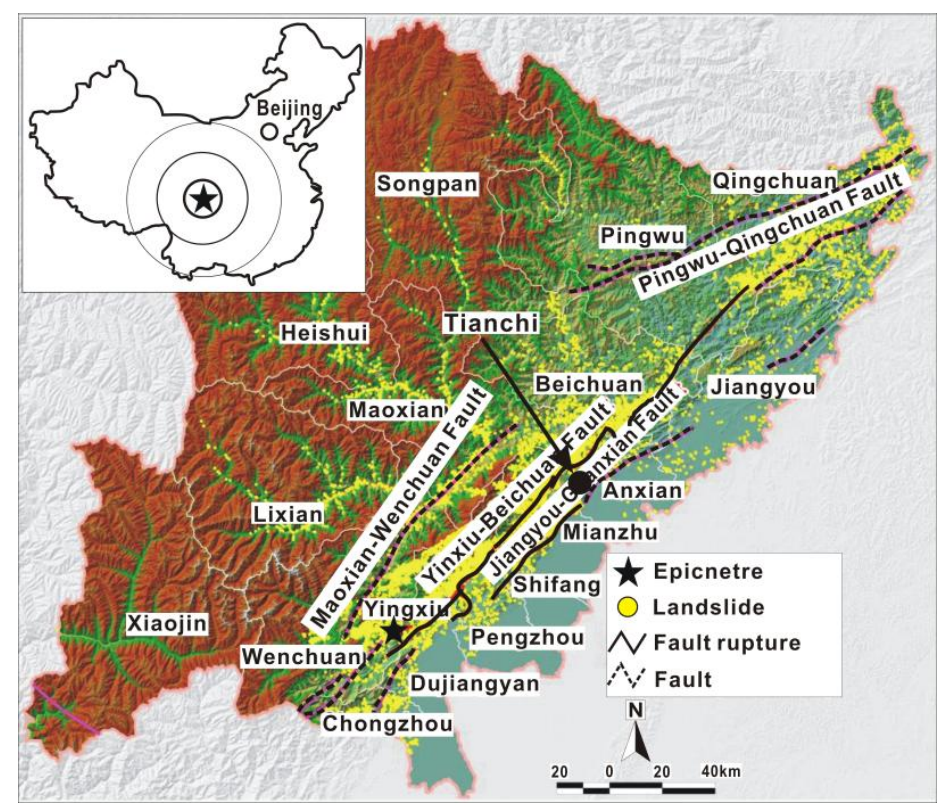

Fig. 1 Epicenter of Sichuan earthquake, distribution of landslides, and location of Tianchi landslide dam (after

Huang and Li (2009)).
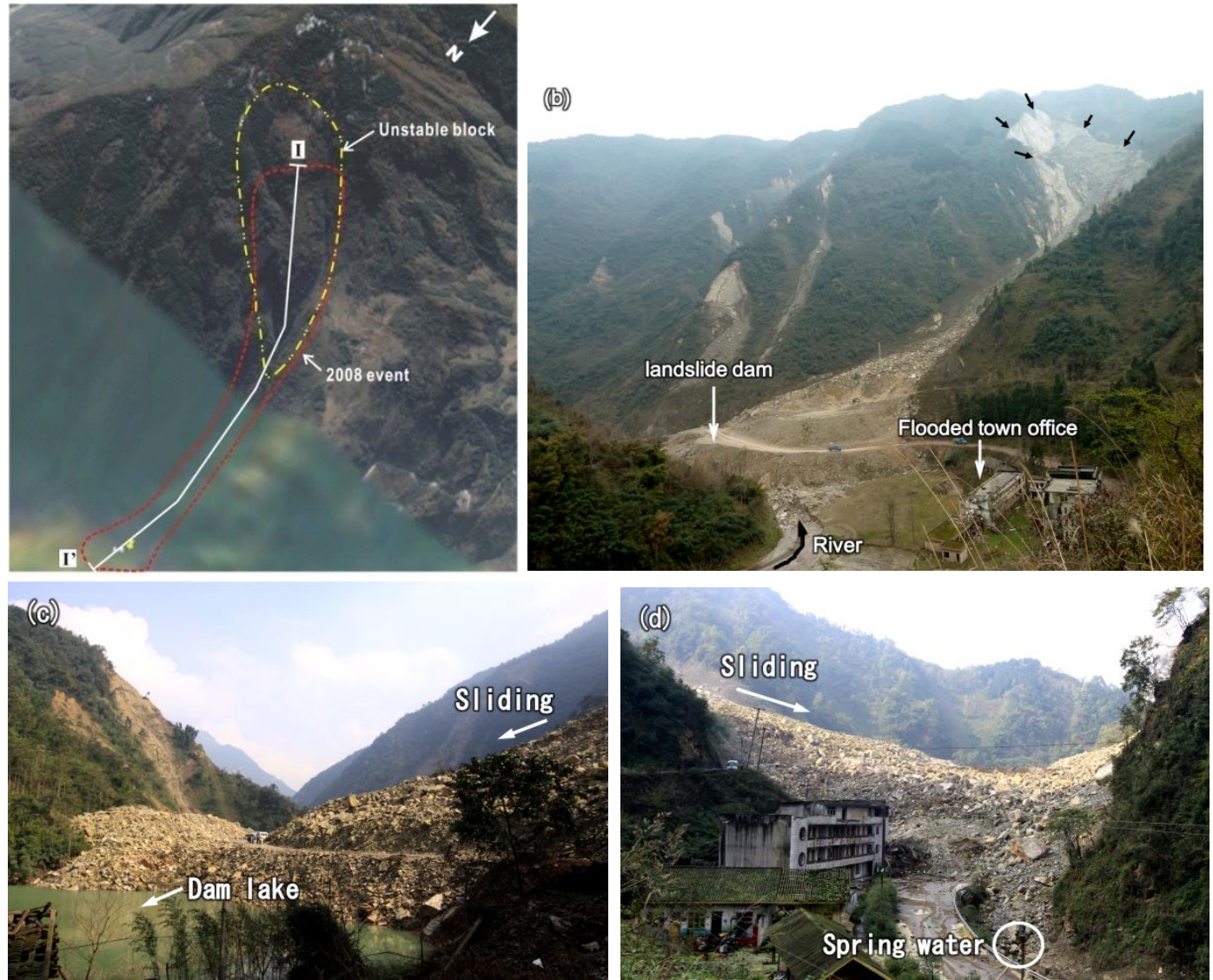

Fig. 2 Landslide dam in Tianchi area. (a) aerial photo of landslide area before the quake; (b) View of the landslide from the upper stream of the river after all construction has been finished (Taken on March 19, 2011); (c) Landslide dam and lake (Courtesy of F. Cai, taken on November 7, 2008 by F. Cai) viewing from upstream; (d):Landslide dam viewing from downstream (Courtesy of F. Cai, taken on November 7, 2008) 




Fig. 3 Geological settings of Tianchi area (1: Stratum boundary; 2: Fault; 3: Tianchi landslide area; 4:


Fig. 4 (a): Source area of the landslide, (b): Stereonet graph of the discontinuities of rocks on the source area 
583

584

585

586

587

588

589

590

591

592

593

594

595

596

597

598

599

600

601

602

603

604

605

606

607

608

609

610

611

612

613

614

615

616

617

618

619

620

621

622

623

624

625

626

627

628

629

630

631

632

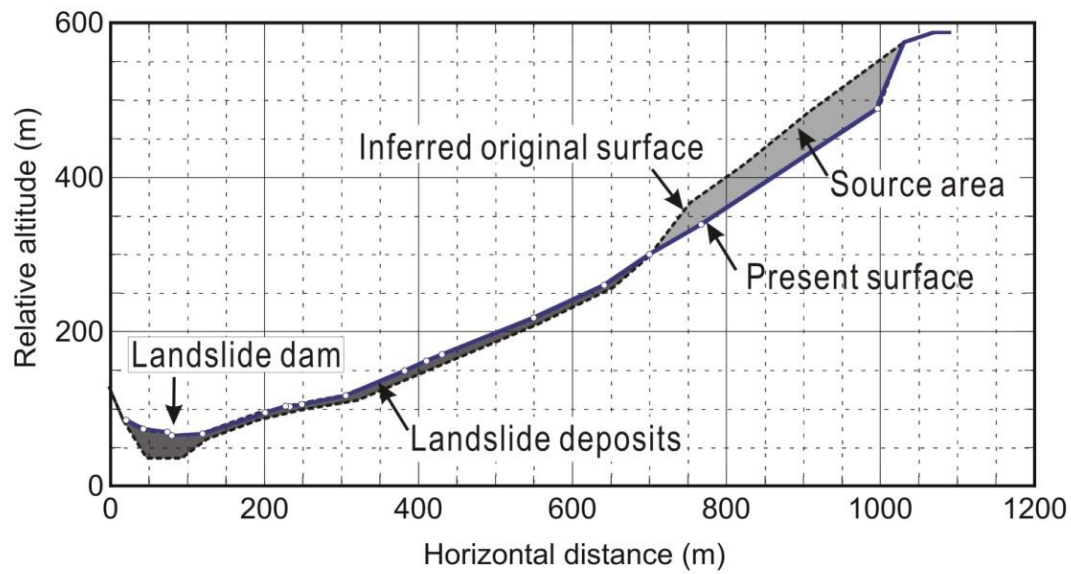

Fig. 5 Longitudinal section along line I-I' in Photo 2a
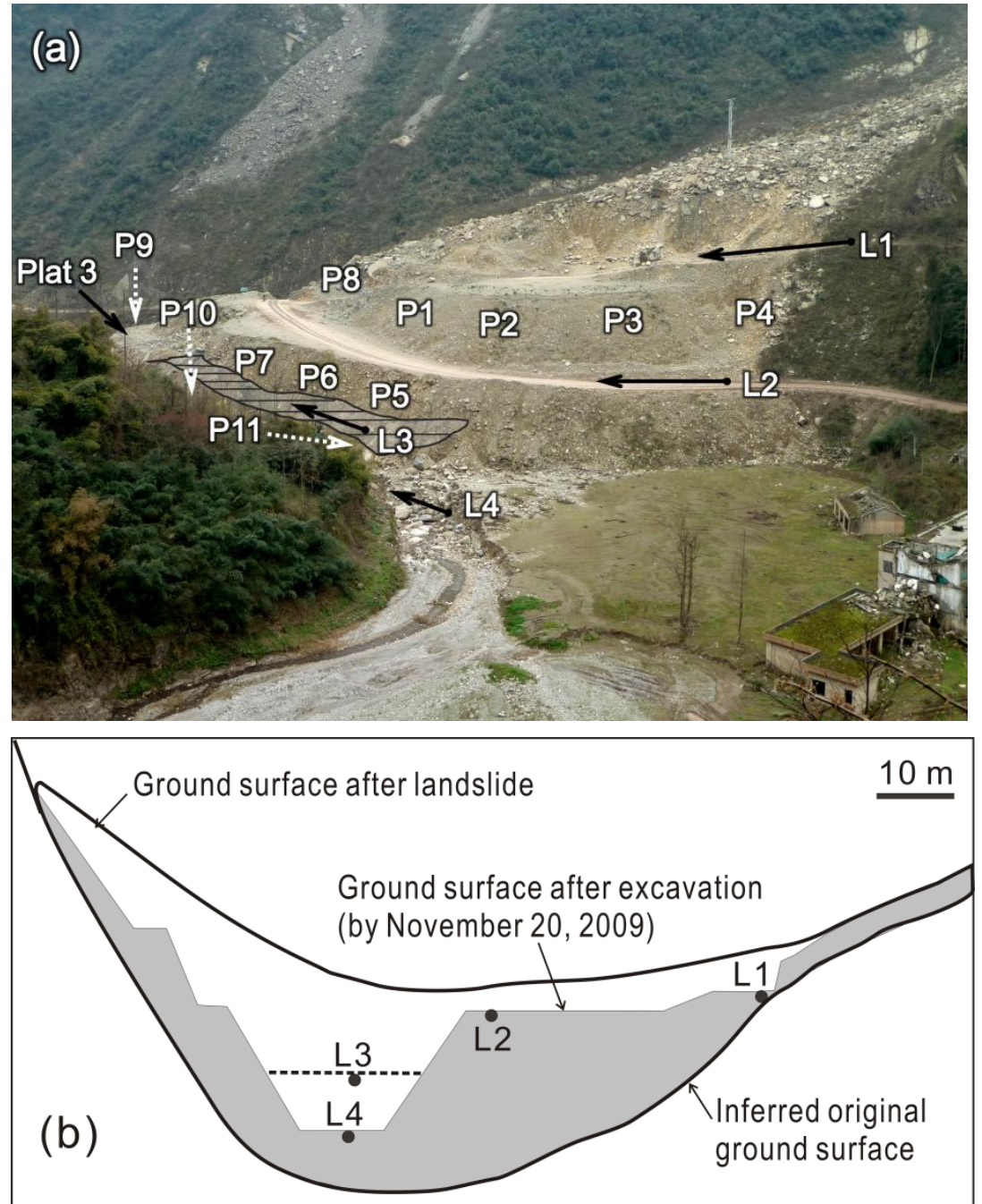

Fig. 6 (a) Photo of landslide dam after excavation with locations of S-wave survey lines and grain size analysis points (P1 P11); (b) Cross section of the landslide dam during differing surveying times. L3, L4: spillway levels on November 20, 2009, and June 16, 2010, respectively. 
633

634

635

636

637

638

639

640

641

642

643

644

645

646

647

648

649

650

651

652

653

654

655

656

657

658

659

660

661

662

663

664

665

666

667

668

669

670

671

672

673

674

675

676
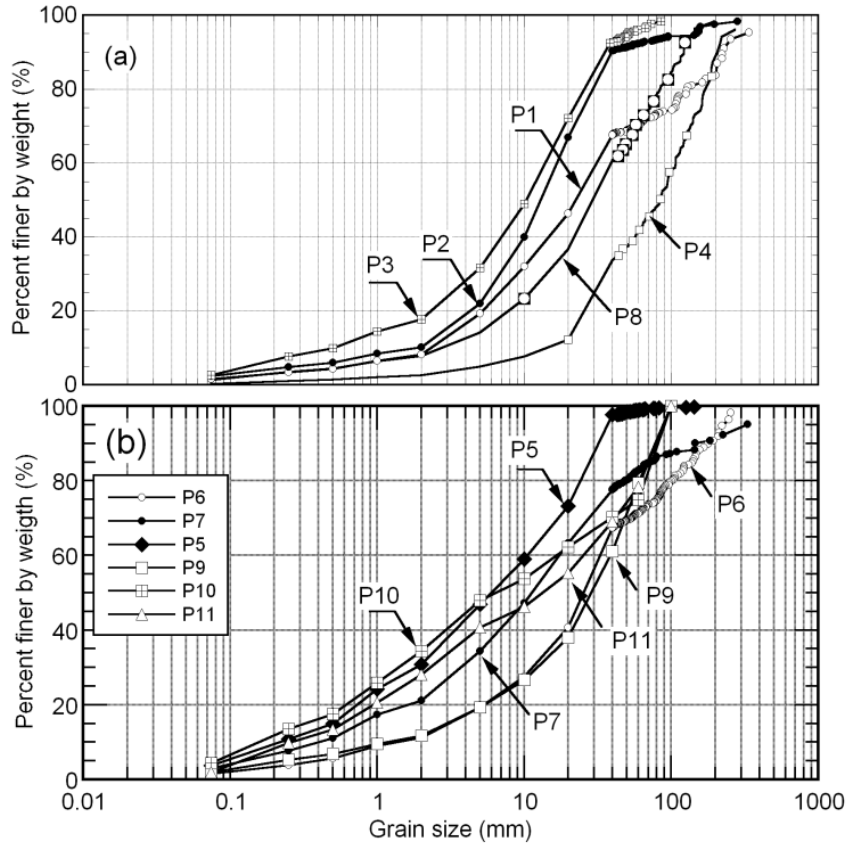

Fig. 7 Grain size distributions of materials from dam body. (a): samples on the same altitude level. (b): Samples at different depth of the dam body

Seismic Source

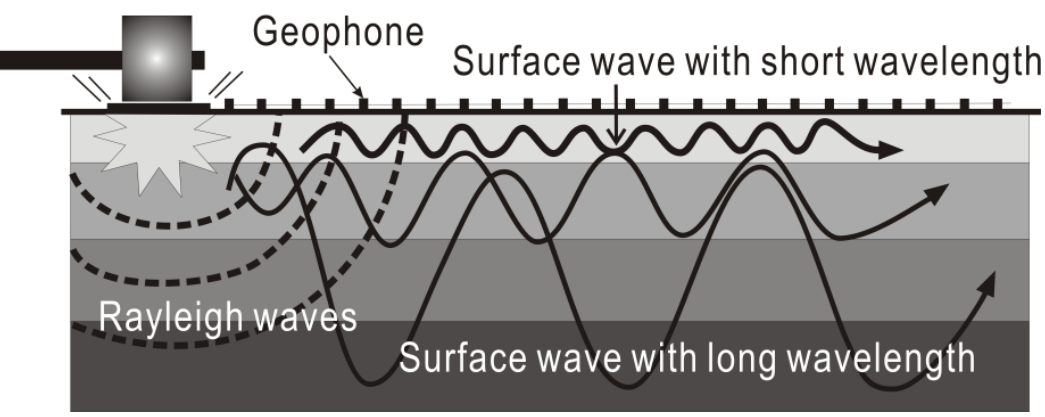

Fig. 8 Measurement principle of multichannel analysis of surface waves (MASW).

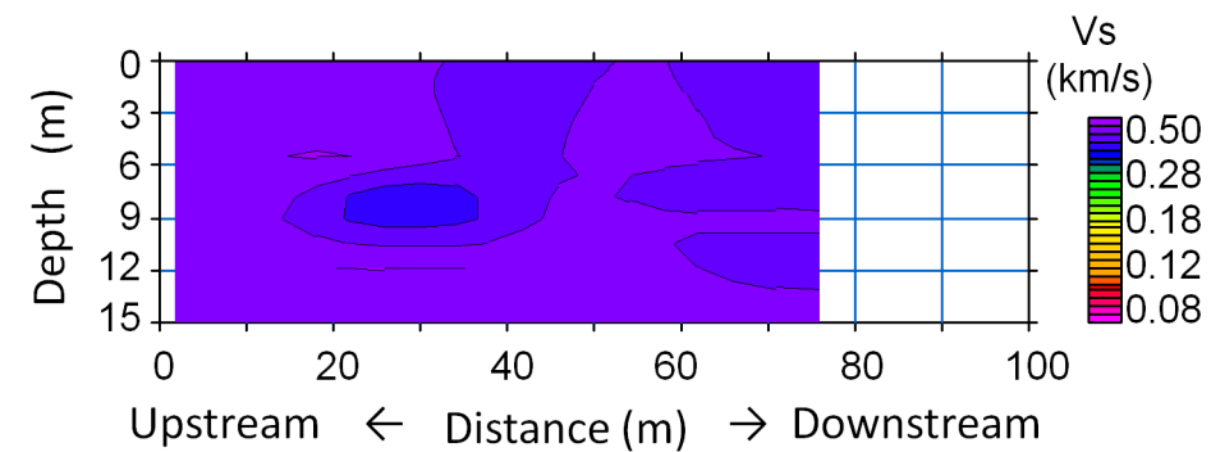

Fig. 9 Shear-wave velocity (Vs) profile along traverse line L1 
677

678

679

680

681

682

683

684

685

686

687

688

689

690
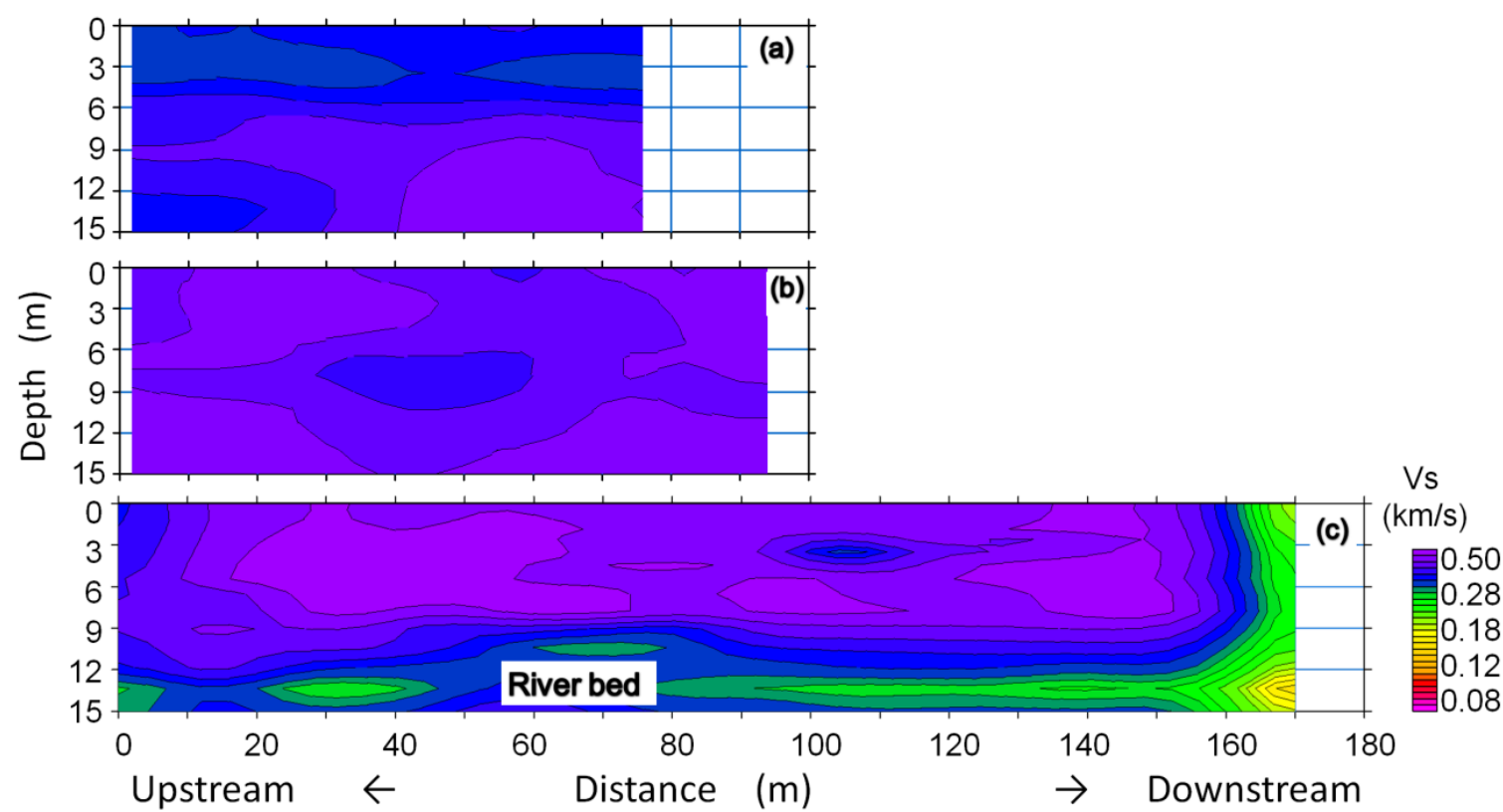

691

Fig. 10 Shear-wave velocity (Vs) profile of the dam body. (a), (b), (c): results for traverse line L2, L3 and L4,

692

respectively

693

694

695

696

697

698

699

700

701

702

703

704

705

706

707

708

709

710

711

712

713

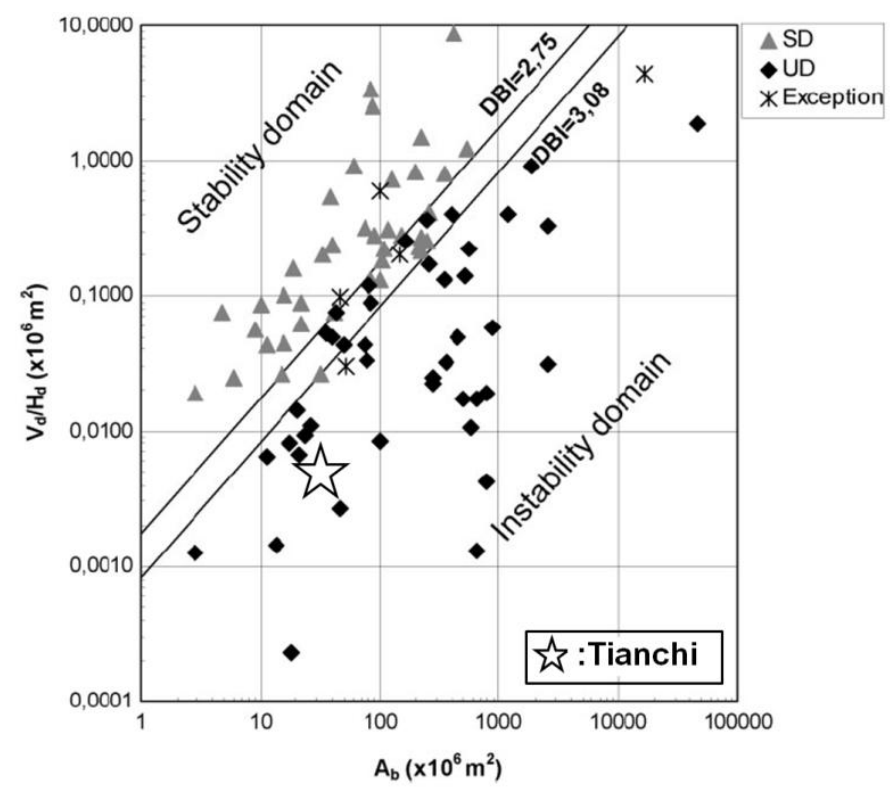

714

Fig.11 Stability analysis using Dimensionless Blockage Index (after Ermini and Casagli (2003)) $\boldsymbol{\Delta}$ : intact landslide dams;

$\checkmark$ : collapsed landslide dams 